\section{Research Article: Leaf area index and yield of cotton -maize cropping systems influence by tillage and land configuration}

\author{
P. PUVILA, K. SIDDESWARAN AND G.MARIAPPAN
}

Article Chronicle : Received :

11.07.2017;

Accepted :

26.07.2017

KeY Words:

FIRB, Flat bed, Conventional tillage, Minimum tillage, Zero tillage

Author for correspondence :

\section{P. PUVILA}

Department of

Agronomy, Tamil Nadu Agricultural University, COIMBATORE (T.N.) INDIA Email: earthpuvi@ gmail.com

See end of the article for authors' affiliations
SUMMARY : : A field experiment with differenttillage practices and land configurations in cotton maize cropping systems was conducted at TNAU, Coimbatoreduring 2011-12 and 2012-13. Totally there were 8 treatments which were replicated thrice in a Randomized Block Design. The treatments consisted of three tillage practices viz., conventional tillage, reduced tillageand zero tillage and three types of land configurations viz., flat bed and furrow irrigated raised bed (FIRB) which were compared with the existing practice of ridges and furrows. The result of two cropping cycles revealed that the growth parameters and seed cotton yield of cotton were higher in the reduced tillage to both cotton and maize and planting on FIRB which was on par with conventional tillage to both cotton and maize and planting on ridges and furrows (existing practice as check), conventional tillage to both cotton and maize and planting on FIRB, reduced tillage to both cotton and maize and planting on FIRB and reduced tillage once to cotton alone and planting on FIRB. In maize, better growth, improved yield parameters and higher yield were recorded in the reduced tillage to both cotton and maize and planting on FIRB.The lowest yield of cotton and maize was recorded in the zero tillage to both the crops and planting on flat bed. In the cotton-maize system, cotton equivalent yield (CEY) was almost similar in reduced tillage to both cotton and maize and planting on FIRB $(4784 \mathrm{~kg} / \mathrm{ha})$, existing practice of conventional tillage to both cotton and maize and planting in ridges and furrows $(4755 \mathrm{~kg} / \mathrm{ha}$ ) and conventional tillage to cotton alone and planting both cotton and maize on the FIRB $(4750 \mathrm{~kg} / \mathrm{ha})$.

How to cite this article : Puvila, P., Siddeswaran, K. and Mariappan, G. (2017). Leaf area index and yield of cotton -maize cropping systems influence by tillage and land configuration. Agric. Update, 12 (TECHSEAR-4): 1037-1041; DOI: 10.15740/HAS/AU/12.TECHSEAR (4)2017/1037-1041. 